DE

M E D I C I N A

T R O P I C A L

$\mathrm{DE}$

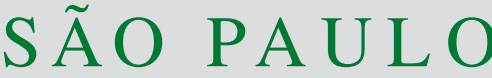

JOURNAL OF THE SÃO PAULO INSTITUTE OF TROPICAL MEDICINE

(1)Universidade de São Paulo, Faculdade de Saúde Pública, São Paulo, São Paulo, Brazil

${ }^{(2)}$ Fundação Oswaldo Cruz, VicePresidência de Pesquisa e Laboratórios de Referência, Rio de Janeiro, Rio de Janeiro, Brazil

${ }^{(3)}$ Centers for Disease Control and Prevention, Division of Global Migration and Quarantine San Diego, California, USA

${ }^{(4)}$ Ministério da Saúde, Secretaria de Vigilância em Saúde, Brasília, Distrito Federal, Brazil

(5)Fundação Oswaldo Cruz, Departamento de Epidemiologia e Métodos Quantitativos em Saúde da Escola Nacional de Saúde Pública Sergio Arouca, Rio de Janeiro, Rio de Janeiro, Brazil

Correspondence to: Robson Bruniera-

Oliveira

Universidade de São Paulo, Faculdade de Saúde Pública, Av. Dr. Arnaldo, 715, CEP 03178-200, São Paulo, SP, Brazil

Tel: +55 12 3842-2369, +55 12 98888-7885

E-mail: robson.bruniera@gmail.com

Received: 12 March 2017

Accepted: 10 July 2017

\section{Epidemiological surveillance of land borders in North and South America: a case study}

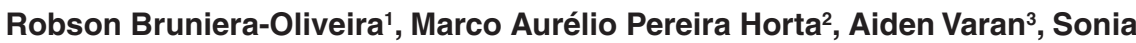 \\ Montiel $^{3}$, Eduardo Hage Carmo ${ }^{4}$, Stephen H Waterman ${ }^{3}$, José Fernando de \\ Souza Verani ${ }^{5}$
}

\section{ABSTRACT}

This study aims to analyze the different binational/multinational activities, programs, and structures taking place on the borders of Brazil and the U.S. between 2013 and 2015. A descriptive exploratory study of two border epidemiological surveillance (BES) systems has been performed. Two approaches were used to collect data: $i$ ) technical visits to the facilities involved with border surveillance and application of a questionnaire survey; $i$ ) application of an online questionnaire survey. It was identified that, for both surveillance systems, more than $55 \%$ of the technicians had realized that the BES and its activities have high priority. Eighty percent of North American and $71 \%$ of Brazilian border jurisdictions reported an exchange of information between countries. Less than half of the jurisdictions reported that the necessary tools to carry out information exchange were available. Operational attributes of completeness, feedback, reciprocity, and quality of information were identified as weak or of low quality in both systems. Statements, guidelines, and protocols to develop surveillance activities are available at the U.S.-Mexico border area. The continuous systematic development of surveillance systems at these borders will create more effective actions and responses.

KEYWORDS: Epidemiological surveillance. Sanitary control of borders. Public health. Communicable diseases. Health communication.

\section{INTRODUCTION}

The epidemics of severe acute respiratory syndrome (SARS), pandemic influenza (H1N1) and Middle Eastern Respiratory Syndrome (MERS-CoV) hit the world with a high pathogenic potential in recent years, providing a warning to nations of the speed with which these epidemics can move across the globe ${ }^{1-3}$. Everyday, nations are more internationally connected ${ }^{4}$. On February 1, 2016, for the fourth time in history, the World Health Organization (WHO) declared a public health emergency of international concern (PHEIC) to make a joint global effort to control the outbreak caused by Zika virus (ZIKV) in Latin America and the Caribbean ${ }^{5,6}$. These facts reiterated the need for governments and international agencies to build and strengthen the surveillance of infectious diseases at all levels, from national to international, thus facilitating the timely detection, response, and communication of disease outbreaks on a global scale ${ }^{4}$.

The International Health Regulations (IHR) recommends that countries sharing borders and having common interests consider establishing multilateral agreements ${ }^{7}$. This aims to facilitate the implementation of IHR, consolidating the direct and rapid exchange of public health information and the application of health 
measures at borders. This effort may prevent and/or control the international transmission of disease at the crossing point $^{7}$. Land borders are physical spaces with peculiar characteristics including large historical, cultural, ethnic, economic, and social heterogeneities. In many cases, these spaces have intense population flows, which create special conditions for disease transmission ${ }^{8}$. Several studies ${ }^{9-14}$ have indicated that these border areas possess different dynamics and patterns of occurrence of disease when compared to other areas within countries.

Brazil and the United States of America (U.S.) are countries with large extensions of land borders. Brazil's border is $15,719 \mathrm{~km}$ long and is shared with ten countries, all with different health policies. The border fringe occupies an area of 2,300,000 $\mathrm{km}^{2}$ (27.6\% of the country), with 588 municipalities and nearly 10 million people $(6 \%$ of the population $)^{15}$. The U.S. Southern border with Mexico extends for $3,141 \mathrm{~km}$, with a fringe of $100 \mathrm{~km}$ ( 62.5 miles) on each side of the border and an estimated population of 13 million people ${ }^{16,17}$.

Due to the long length of land borders, with intense population flows and different epidemiological and social scenarios, the vulnerability to the introduction and rapid spread of potential threats to public health is a fact that must be taken into consideration. Therefore, the development of systems and activities focusing on border epidemiological surveillance (BES) is essential both for domestic and global health security ${ }^{18}$. Based on the hypothesis that border surveillances must promote binational communication, an exchange of epidemiologic information in a timely and dynamic manner to improve the cross-border public health infrastructure through collaboration, this study aimed to analyze the different binational/multinational activities, programs, and structures to identify challenges and to suggest improvements of binational and/or multinational epidemiological surveillance partnerships on the borders of Brazil and the U.S.

\section{MATERIAL AND METHODS}

A descriptive exploratory study about border epidemiological surveillance (BES) systems was performed in South and North America between 2013 and 2015. A total of 47 interviews at every operational level of the BES were conducted at the United States-Mexico border (US-MX border applied from February 2014 to September 2014) and Brazil (November 2014 to March 2015).

\section{Description of the study area}

In South America, the study focused on the border between Brazil and the America's Southern Cone countries (Argentina, Paraguay, and Uruguay). This border area is defined as the area of land situated $150 \mathrm{~km}$ North and South from the International Boundary Line. This region is divided into six subregions (XII-XVII) with 441 municipalities, an area of $329,943 \mathrm{~km}^{2}$ and a population of $6,893,804$ inhabitants ${ }^{19}$ (Figure 1).

As for North America, the study was carried out on the Southern U.S. border with Mexico. This border has a length of approximately $3,141 \mathrm{~km}$. The border region is defined as the area of land situated $100 \mathrm{~km}$ (62.5 miles) North and South from the international boundary. The area includes four U.S. States (California, Arizona, New Mexico, and Texas) and six Mexican States (Baja California, Sonora, Chihuahua, Coahuila, Nuevo Leon, and Tamaulipas) with an estimated population of about 13 million people ${ }^{17}$ (Figure 2).

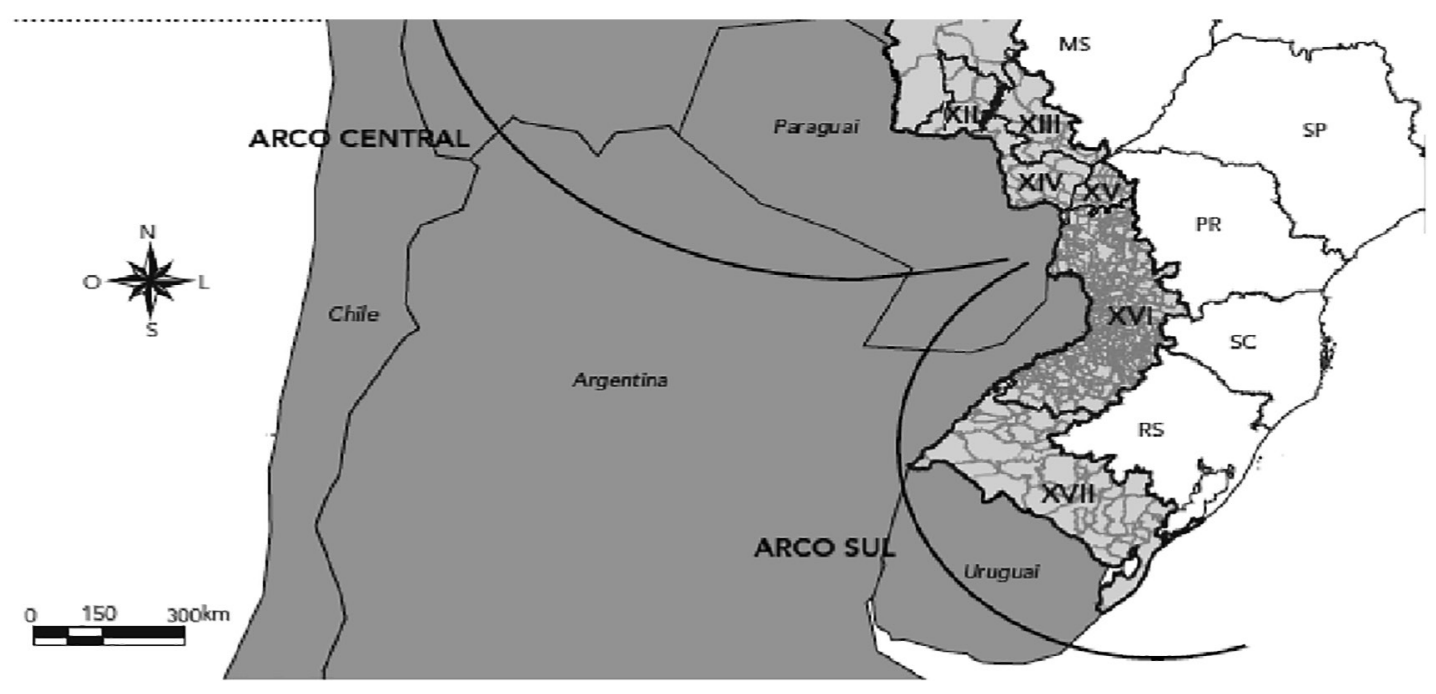

Figure 1 - Map -illustrating the border regions between Brazil and the Mercosur member countries. Source: Peiter ${ }^{15}$ 


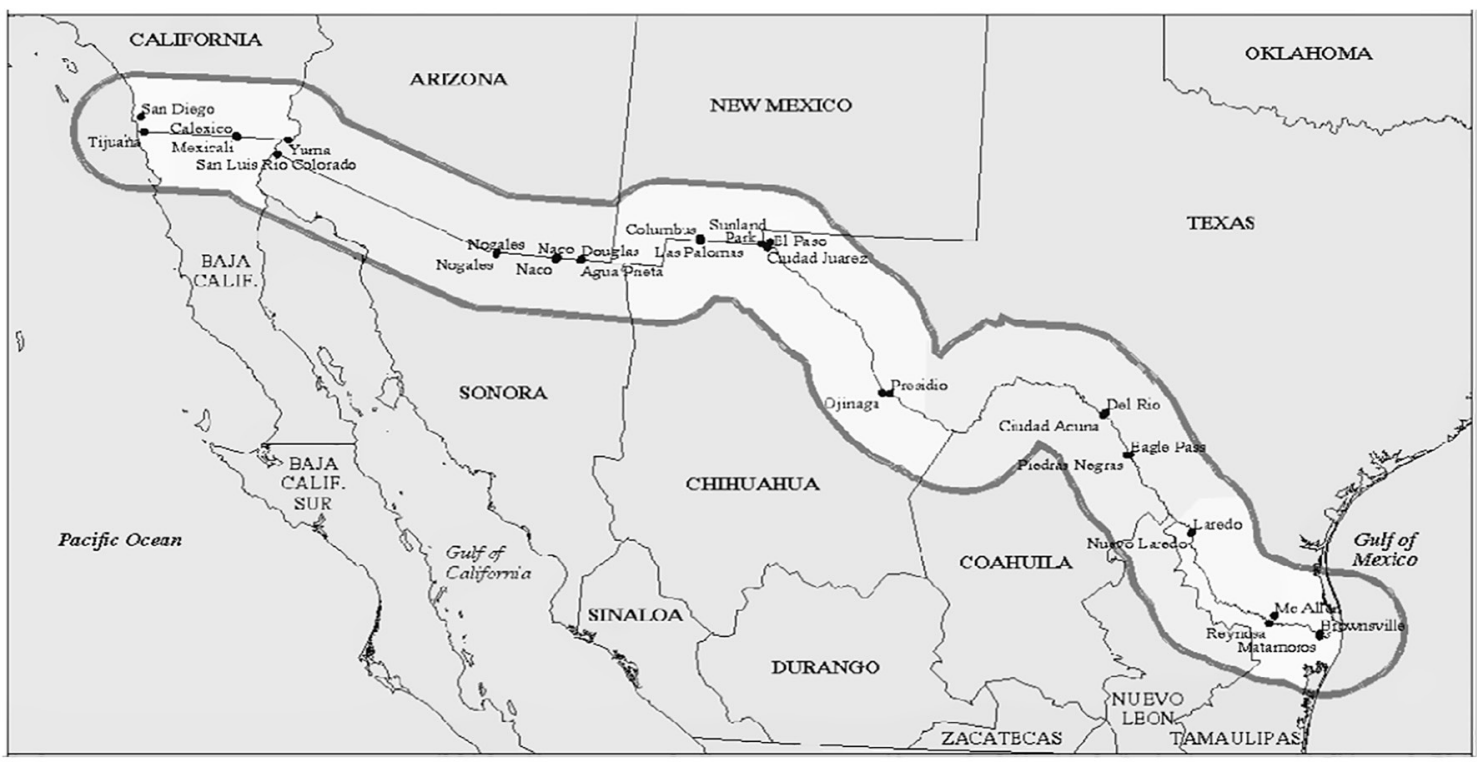

Figure 2 - US-Mexico border. Source: http://www.borderhealth.org/border_region.php

\section{Data collection and analysis}

BES operational data were collected using a developed semi-structured questionnaire with a focus on information exchange between jurisdictions, domestically and internationally. The instrument was based on previous surveys by the $\mathrm{CDC}^{20}$, Bruniera-Oliveira et al..$^{21}$ and Varan et al. ${ }^{22}$ and was structured with four dimensions: organizational priorities and resources, information exchange, laboratory, and challenges.

Because of long geographical distances, two approaches were used for data collection: $i$ ) technical visits to the facilities involved with border surveillance, which included questionnaire applications and direct observations of the operational procedures and facility structures; $i i$ ) application of online questionnaires for those facilities that could not be visited. For both approaches, questionnaires were developed in English and, subsequently, translated into Spanish and Portuguese.

A draft questionnaire was shared with stakeholders in all operational levels working directly or indirectly on border surveillance activities in the U.S. for comments and suggestions. A pilot test of a final version of the tool was conducted with U.S. and Mexico stakeholders to evaluate its effectiveness to collect information. A Likert scale was used to measure the outcomes ${ }^{23-25}$. The final version of the English questionnaire was translated and back-translated by native speakers of Spanish and Portuguese, which subsequently went through the same validation process by experts. For the questionnaire application by digital media, an online survey development software, SurveyMonkey, was used (Research SurveyMonkey ${ }^{\circledR}$ ). Its distribution and monitoring were done through links distributed by e-mail to the participants' e-mails.

Technical visits were carried out at agencies, institutions and partners (such as health surveillance agencies, immigration departments, national or multinational committees/groups, laboratories, etc.), proceeding with document analysis, organization observation, and operational structure and involvement of professionals with surveillance activities. During the visits, interviews were conducted with BES stakeholders in their various operational levels using the questionnaire that had been developed. In the absence of the technician in charge in the facilities visited or in areas where visit was not possible, the stakeholders were invited to answer the online questionnaire.

When a respondent had questions about the questionnaire or the researcher had questions about responses, a phone interview or web conference was conducted. The scope of the questionnaire included some operational attributes of surveillance, such as completeness, reciprocity, opportunity, feedback, and the quality of information. These attributes were analyzed from the perspective of the respondents using the Likert scale for measurement. This research was approved by the Research Ethics Committee of the National School of Public Health Sergio Arouca (CEP / ENSP), under the $\mathrm{N}^{\circ} 699.241$.

\section{RESULTS}

\section{Operational profile of the respondents}

A total of 47 stakeholders were interviewed. Thirty of 
these technicians were from the North-American BES (20 technicians from the U.S. and 10 from Mexico), while in South America all the 17 technicians were from Brazil. The majority of respondents in Brazil and half in the United States belonged to the local health municipalities, whereas the State level in Mexico was the most frequent in the interviews (Table 1).

\section{Operational characteristics of the systems}

The U.S. has developed programs and specialized structures in border surveillance, such as the Borders Office, quarantine stations (QS), and important partnerships with several agencies that provide support with any suspected case of an important binational disease (Table 1). Brazil does not have such structures. However, it does have Customs and Border Protection (CBP) and border offices in its structural organization, and organization stations called the Health Surveillance Stations of Ports, Airports, Borders and Customs Enclosures (PVPAF) of the Brazilian Sanitary Surveillance Agency (ANVISA). These stations are located at strategic points in Brazil, 17 of which are on land borders. Surveillance activities and sanitary control of goods, people, and animals are carried out at these stations, and some facilities have agreements with regional hospitals for the displacement and isolation of suspected cases of infectious diseases of public health concern. In addition, some of these stations are located on borders that have bior multinational facilities, a fact that makes the interaction between countries easier and more timely (Table 1 ).

In both surveillance systems, more than $55 \%$ of the technicians at several operational levels realize that the BES and their activities (detection, investigation, and binational or multinational notification) are high priority. Nevertheless, for these technicians, the nonexistence and/ or availability of a formal protocol with the neighboring country is considered a limiting factor for the development of appropriate actions. Only 38\% of respondents in South America are familiar with the contact points involved in the notification and binational investigation. This proportion increases to $55 \%$ on the U.S.-Mexico border where there are available statements, guidelines, and protocols to develop joint activities in the border areas (Table 2). A specific document, the "U.S. Mexico Binational Communication Pathways Protocol," for the land border deserves to be highlighted. This document has been improved since 2002 by several technicians at several operational levels of the two countries and proposes to systematize and enhance the exchange of information mechanisms ${ }^{26}$.

Information exchange between countries occurs in more than $80 \%$ of North American jurisdictions and $71 \%$ percent of the Brazilian jurisdictions; however, only the U.S. and Mexico's technicians consider this exchange timely. Brazilian and U.S. technicians identified the reciprocity of

Table 1 - Profile of the respondents, geographic and operational characteristics of the Borders Epidemiological Surveillance System

\begin{tabular}{|c|c|c|c|c|}
\hline & & \multicolumn{2}{|c|}{ US-Mexico Border } & \multirow{2}{*}{$\begin{array}{c}\text { Brazilian Border } \\
\text { Brazil }\end{array}$} \\
\hline & & U.S & Mexico & \\
\hline \multicolumn{5}{|c|}{ Profile of the respondents } \\
\hline Number of respondents & & 20 & 10 & 17 \\
\hline \multirow[t]{4}{*}{ Operational Level of Respondents } & Federal & 4 & - & 4 \\
\hline & State & 6 & 6 & 3 \\
\hline & Local & 6 & 3 & 8 \\
\hline & Laboratories & 4 & 1 & 2 \\
\hline \multicolumn{5}{|c|}{ Geographic characteristics } \\
\hline Border Extension & & \multicolumn{2}{|c|}{$3.141,0$} & $3.694,8$ \\
\hline Number of Countries Bordering & & \multicolumn{2}{|c|}{1} & 03 \\
\hline Twin Cities & & \multicolumn{2}{|c|}{34} & 21 \\
\hline Population & & \multicolumn{2}{|c|}{12.000 .000} & 6.186 .840 \\
\hline Points of Entry & & \multicolumn{2}{|c|}{43} & numerous \\
\hline \multicolumn{5}{|c|}{ Operational characteristics } \\
\hline \multicolumn{2}{|l|}{ Presence of Quarantine Station } & \multicolumn{2}{|c|}{ Yes } & No \\
\hline \multicolumn{2}{|l|}{ Border Offices } & \multicolumn{2}{|c|}{ Yes } & No \\
\hline \multicolumn{2}{|l|}{ Border Type (open or closed) } & \multicolumn{2}{|c|}{ Closed } & Open \\
\hline
\end{tabular}


Table 2 - Organizational priorities, information exchange and Binational Notification of the Borders Epidemiological Surveillance System

\begin{tabular}{|c|c|c|c|c|c|}
\hline & & & \multicolumn{2}{|c|}{ US-Mexico Border } & \multirow{2}{*}{$\frac{\text { Brazilian Border }}{\text { Brazil }}$} \\
\hline & & & U.S & Mexico & \\
\hline \multicolumn{6}{|c|}{ Organizational priorities } \\
\hline \multirow{3}{*}{\multicolumn{2}{|c|}{$\begin{array}{l}\text { Border surveillance is recognized as a } \\
\text { priority for }\end{array}$}} & Federal & $55 \%$ & $78 \%$ & $62 \%$ \\
\hline & & State & $55 \%$ & $78 \%$ & $44 \%$ \\
\hline & & Local & $65 \%$ & $78 \%$ & $77 \%$ \\
\hline Binational notific & $\mathrm{n}$ is recognized as & & High & & High \\
\hline \multicolumn{6}{|c|}{ Information exchange and Binational Notification } \\
\hline \multicolumn{3}{|c|}{ Availability of Protocol } & $45 \%$ & $33 \%$ & $29 \%$ \\
\hline \multicolumn{3}{|c|}{$\begin{array}{l}\text { Clarity and Well defined of the pathways for communication be- } \\
\text { tween binational public health agencies }\end{array}$} & $40 \%$ & $22 \%$ & $10 \%$ \\
\hline \multicolumn{3}{|c|}{$\begin{array}{l}\text { Familiarity with the contact points involved with the binational } \\
\text { notification }\end{array}$} & $55 \%$ & $56 \%$ & $38 \%$ \\
\hline \multicolumn{3}{|c|}{ Occurrence of binational exchange of epidemiologic information } & $80 \%$ & $90 \%$ & $71 \%$ \\
\hline \multicolumn{3}{|c|}{ Timeliness of epidemiological information sharing } & Always & Always & Never \\
\hline \multicolumn{3}{|c|}{ Reciprocity of epidemiological information } & $25 \%$ & $33 \%$ & $40 \%$ \\
\hline \multicolumn{3}{|c|}{ Feedback and Follow-up of the information } & Low & Low & Low \\
\hline \multicolumn{3}{|c|}{ Completeness of the epidemiological information } & Poor-Fair & Poor-Fair & Poor-Fair \\
\hline \multicolumn{3}{|c|}{ Quality of the epidemiological information } & Poor-Fair & Poor-Fair & Poor-Fair \\
\hline \multicolumn{3}{|c|}{$\begin{array}{l}\text { Availability of necessary tools to carry out the exchange of bina- } \\
\text { tional information }\end{array}$} & $35 \%$ & $45 \%$ & $46 \%$ \\
\hline \multirow{4}{*}{$\begin{array}{l}\text { Mechanisms } \\
\text { for binational } \\
\text { communication }\end{array}$} & Electronic web sys & em communications & $42 \%$ & $71 \%$ & $50 \%$ \\
\hline & Telephone & & $14 \%$ & $71 \%$ & $50 \%$ \\
\hline & Fax & & $29 \%$ & $15 \%$ & $50 \%$ \\
\hline & $\begin{array}{l}\text { There are no me } \\
\text { communication }\end{array}$ & hanisms of binational & $15 \%$ & $42 \%$ & $50 \%$ \\
\hline \multicolumn{3}{|c|}{$\begin{array}{l}\text { Established mechanisms for sharing personally identifiable in- } \\
\text { formation (PII) }\end{array}$} & $40 \%$ & $22 \%$ & $29 \%$ \\
\hline
\end{tabular}

sending information as a failure. The feedback and followup of epidemiological information was considered low by all stakeholders.

The quality and completeness of exchanged information were considered medium to weak in the scale used. Less than half of the jurisdictions have the necessary tools to carry out information exchange. Telephone and electronic means of communication, such as e-mail, are most commonly used for information exchange. Over $50 \%$ of respondents reported a lack of mechanisms for sharing personally identifiable information (PII), such as encrypted e-mails (Table 2).

\section{Organizational priorities}

In both investigated systems, the priorities and actions are defined in binational meetings involving various partners. In South America, the Comitê Interfronteiriço and the Grupo Técnico de Itaipu Saúde are important mechanisms to outline surveillance activities. On the U.S.-MX border, groups and meetings, such as the Binational Joint Operational Meeting, the Epi Meeting, the Border Epidemiology and Surveillance Team (BEST) meeting, as well as the Consejo Binacional de Salud, among others, are important mechanisms used to share data to collaborate. It should be stressed that, in South America, there was no evidence of participation of organizations, such as the Pan American Health Organization (PAHO), MERCOSUR, or the Union of South American Nations (UNASUR) in any local border activities. The U.S.-MX border used to have a PAHO's border office in El Paso, which acted as facilitator of the collaboration between the U.S. and Mexico. However, this office ceased its activities in 2014 . 


\section{Human, financial resources and inputs}

The limited availability of funds and specific resources is a major obstacle in the development of BES in Brazil and Mexico. Eighty percent of U.S. respondents reported the availability of financial and human resources from the three operational levels of administration. The training for technicians, including laboratory workers, is present in both systems. The respondents in the two surveyed areas consider that the U.S. and Brazil (for having more economic and financial capacity) should provide more support to the activities of their neighboring countries. Differences between countries make the border actions being implemented often only on the U.S. or Brazilian side (Table 3).

\section{Laboratories}

In the U.S.-MX border review, local laboratories mainly process samples of cases under investigation. In Brazil, an emphasis should be given to the Border Laboratories'
Network, coordinated by the Brazilian Health Surveillance Secretariat (SVS/MS), which consists of 12 laboratories located along the Brazilian border (Figure 3). This network was created to develop the capacity and opportunity for detection of major communicable diseases, lowering the demands on the Central Laboratory of Public Health (LACEN).

Regarding the laboratory support to BES, some similarities between the two areas' borders were identified. Diagnostic and quality control panels testing methods are standardized and harmonized among laboratories within the countries, but it is not standardized among counterpart laboratories. Technology and cooperation exchange was observed between countries, but at a low frequency. Respondents believe that the financial resources and inputs are not sufficient to conduct all laboratory activities. However, on the Brazilian side, those technicians believed that they had the sufficient number of technicians to respond to all the demands of their laboratories - a fact not observed in U.S. and Mexican laboratories. The low frequency of training was cited as a major obstacle. Documents that

Table 3 - Human, financial and technical support, Laboratory and Challenges of the Borders Epidemiological Surveillance System

\begin{tabular}{|c|c|c|c|c|}
\hline & & \multicolumn{2}{|c|}{ US-Mexico Border } & Brazilian Border \\
\hline \multicolumn{5}{|c|}{ Human, Financial Resources and technical support. } \\
\hline & & U.S & Mexico & Brazil \\
\hline \multicolumn{2}{|c|}{$\begin{array}{l}\text { Availability of resources in your country specifically } \\
\text { allocated to carry out the binational surveillance } \\
\text { activities }\end{array}$} & $80 \%$ & $22 \%$ & $11 \%$ \\
\hline \multicolumn{2}{|l|}{ Technician's training } & Present & Present & Present \\
\hline \multicolumn{2}{|c|}{$\begin{array}{l}\text { Support (personnel, technical and financial support) } \\
\text { to the neighboring country }\end{array}$} & $95 \%$ & $63 \%$ & $88 \%$ \\
\hline \multicolumn{5}{|c|}{ Laboratory } \\
\hline \multirow{2}{*}{$\begin{array}{l}\text { Laboratory testing } \\
\text { methods and quality } \\
\text { control panels } \\
\text { standardized and } \\
\text { harmonized with }\end{array}$} & $\begin{array}{l}\text { Your country (between } \\
\text { jurisdictions) }\end{array}$ & $52 \%$ & $78 \%$ & $87 \%$ \\
\hline & $\begin{array}{l}\text { With your neighboring } \\
\text { Country }\end{array}$ & $55 \%$ & - & $16 \%$ \\
\hline \multicolumn{2}{|c|}{$\begin{array}{l}\text { Collaboration, support and / or exchange of tech- } \\
\text { nology }\end{array}$} & Present & Present & Present \\
\hline \multicolumn{2}{|c|}{$\begin{array}{l}\text { The financial resources available is sufficient to carry } \\
\text { out laboratory activities }\end{array}$} & $35 \%$ & $44 \%$ & $43 \%$ \\
\hline \multicolumn{2}{|c|}{$\begin{array}{l}\text { The human resources available is sufficient to carry } \\
\text { out the laboratory activities }\end{array}$} & $35 \%$ & $44 \%$ & $60 \%$ \\
\hline \multicolumn{2}{|c|}{$\begin{array}{l}\text { Cross border laboratory training occur at least once } \\
\text { a year }\end{array}$} & $52 \%$ & $75 \%$ & $20 \%$ \\
\hline \multicolumn{2}{|c|}{$\begin{array}{l}\text { Availability document which regulates how it should } \\
\text { operate the flow of information and samples }\end{array}$} & Absent & Absent & Absent \\
\hline \multicolumn{5}{|c|}{ Challenges } \\
\hline \multicolumn{2}{|c|}{ Language as a barrier for binational surveillance } & Important & Moderately important & Of little importance \\
\hline \multicolumn{2}{|c|}{ Differences in health systems between } & Differences hinder a lot & Moderate problem & Minor problem \\
\hline
\end{tabular}


regulate the flow of information and samples of binational cases in the two borders were not identified (Table 3).

\section{Main challenges identified by respondents}

Although the countries involved in this study have different health organization systems and speak different languages, few technicians identified these differences as barriers to develop BES activities. In general, the major obstacle highlighted to the exchange of information and joint activities was the lack of guidelines describing the steps of binational disease notification and investigation (Table 3).

\section{DISCUSSION}

Acknowledging the vulnerability of introducing and spreading potential public health events through land borders, the International Health Regulations (IHR) recommends that countries sharing common borders should consider establishing bilateral or multilateral agreements about strengthening surveillance actions at ground crossings ${ }^{7}$.

In larger border areas, such as those of the U.S. and Brazil, there are large numbers of residents. Together with the intense population flow, this provides a favorable scenario for the occurrence and spread of communicable and noncommunicable diseases ${ }^{8,27}$. Ferraz et al. ${ }^{28}$ and Spradling et al..$^{29}$ pointed toward different profiles of tuberculosis and acute viral hepatitis in the border regions of Brazil and the United States, respectively, when compared with States and national rates. Thus, the inclusion and prioritization of BES activities, mainly at the local and federal levels, are an important step toward consolidation of health surveillance systems reflecting the recognition of the importance of the issue by the governments.

However, as observed in this study (particularly in South America), findings show that it lacks certain protocols. These protocols, as observed at the U.S.-MX border, define the actions and communication flows between public health agencies involved with binational notifications and may support adequate responses to the occurrence of public health events. Wang et al..$^{30}$, studying vaccine-derived poliovirus (VDPV) outbreaks, noted that surveillance based on solid international collaboration and agreements with clear and well-defined paths allows for an exchange of information in a timely and dynamic manner. The contribution of such agreements was critical to avoid the VDPV outbreaks from reaching China through its land borders. The inadequacy of many surveillance indicators (lack of opportunity for the exchange of epidemiological information, quality of the epidemiological information, reciprocity, feedback, and incompleteness of information) may be related to the informality of the BES operational articulation.

BES systems in North and South America have taken important steps toward systematizing their activities. Both international borders are defining their priorities and actions in these regions together with stakeholders and partners of the neighboring countries. North American countries have developed and distributed a document detailing the step-by-step operational flow of information and actions because these countries place a higher priority on their actions. BES services that have developed and implemented such protocols and plans result in more clear and efficient conduction, evaluation, and review of operational procedures. In addition, the activities are not linked to specific individuals, but are rather institutionalized, allowing the continuity of standard procedures and minimizing disruptions to required actions.

A lack of human, technical, and financial resources were major obstacles in Brazil and Mexico. Scarcity of primarily financial resources to hire technicians weakens the systems of these two countries. The lack of technicians and high personnel turnover at the jurisdiction level creates a burden on the technical staff, affecting the necessary epidemiological actions. In this respect, Bruniera-Oliveira et al. ${ }^{21}$ evaluated Brazil's rotavirus epidemiological surveillance, noting that the limited number of technicalities and high turnover caused a delay in the process, transfer and response of the rotavirus surveillance.

The need for a greater investment in human, technical, and financial resources was unanimous by respondents in both of the studied areas. It is possible that many of the process difficulties, particularly information exchange, are due to structural differences between the countries involved. While, in Brazil there is a system that facilitates mechanisms to carry out information exchange quickly and confidentially, other countries are using unsafe means for information exchange. This structural discrepancy generates resistance, especially when health services are dealing with personal information. Furthermore, there are mechanism incompatibilities, such as differences in software versions used or even lack of such mechanisms. Therefore, countries with available resources should seek ways to standardize communication mechanisms ${ }^{26}$.

Particular attention should be given to laboratories, which provide support for border surveillance. For most of the infectious diseases of public health concern, laboratory confirmation is essential for planning and triggering the control and prevention actions. Thus, the organization of a laboratory network able to meet demands of the 
border areas would increase sensitivity, opportunity, and system specificity ${ }^{31}$. In North America, due to the systems developed at the borders, such as the Border Infectious Disease Surveillance (BIDS), there was a substantial reduction in disparities with surveillance capabilities in incompatibility of used case definitions. This resulted in increased diagnostic capacity and laboratory capability in the region ${ }^{9}$.

In Brazil, the Border Laboratories Network can be considered innovative as it seeks to reduce the differences in laboratory capacity between countries. However, despite what has been developed so far, significant obstacles were identified, such as a lack of support from federal laboratories and no standardization of techniques among countries. This hindered comparisons and the planning of binational actions. A study about the occurrence of public health emergencies in Brazil proved that, in the border areas, laboratory confirmation remains low for suspected cases $^{21}$. This lack of diagnosis can be attributed to the high testing demand that these laboratories have, which requires additional investment for its expansion and an increase of capacity to become a robust border network. Although one of the response pillars to the Ebola outbreak in West Africa has been the laboratory support, the lack of capacity during the early stages of the epidemic was undoubtedly a factor that contributed to Ebola's rapid expansion, reinforcing the idea of consolidating a prepared network to respond to any type of threat ${ }^{32,33}$. Such difficulties in the BES development, including laboratory services, may have contributed to a weak capacity to detect and respond in a timely manner to public health events, as observed for the Brazilian international border municipalities ${ }^{34}$. The analysis of their capacity to report infectious diseases with a potential to generate an epidemic demonstrated a very low proportion $(16,6 \%)$ of cases of these diseases being reported in a timely manner ( $<24$ hours - as established nationally).

The political organization of different countries for the entry and movement of people through borders are relevant factors in the comparison of surveillance systems and in the design of health systems for the border regions. The Treaty of Asunción, which gave rise to MERCOSUR, establishes that the States' parties have the freedom of movement for people, goods, and services among them ${ }^{35}$. Hence, the Brazilian Southern Border Arc has an extremely high daily porosity for people entry and exit, once the crossing between countries can be taken without any impediment. As evidenced by the research, there are numerous points of entry, where there are no checkpoints, such as health inspection points or customs. On the other hand, in North America, in addition to the physical barriers along the border, all entry points are controlled by U.S. Customs and Border Protection (CBP). This agency first screens incoming international travelers with the CDC and has the power to detain for the enforcement of isolation and quarantine of individuals with any signs and/or symptoms of infectious diseases ${ }^{36}$. The presence of such agencies as the CBP plays an important role in the containment of infectious diseases entering the United States. Countries that applied travel restrictions on their borders during the epidemic of the influenza virus A (H1N1) observed that both the restriction and the isolation and quarantine of the cases played an important contribution in the delay of the virus in their countries ${ }^{37,38}$.

The lack of a screening process at the border crossing points temporarily makes the detection of potential suspect cases very passive, dependent on volunteers seeking health assistance. The receiving health facility of a suspected case must be prepared to provide the initial care to isolate the case when necessary or make the transport to the place of isolation. They must then communicate in a timely manner with the respective authorities in the neighboring country to begin the binational investigation. Moreover, all health facilities in the border region, including laboratories, must be notified about the possible suspect cases. An online system for binational notification would be the tool of choice. All levels involved in the response could then input, search, and follow up in real time on all the epidemiological information of cases, thus creating increased transparency and dynamism to the response process. Inside this network, an important movement should be made to bring international organizations closer, such as PAHO and multilateral mechanisms, as MERCOSUR and UNASUR. These structures and mechanisms should have important tools that have been created for international health dialogue so they can act as front ambassadors to stalemates when an urgent international response is required. Forums and mechanisms created by these agencies are important health authorities of the participating countries. Due to the previous meetings, they already have affinities, which facilitate and streamline the dialogue and target the most controversial issues.

One of the limitations of this study was the voluntary participation, which made some of the invited stakeholders/ key coordinators not available to answer the survey. Another limitation was the financial aspect, which restricted the field visit to just one point of entry into South America. Specifically, in the South Arc, obtaining responses from Paraguayan technicians would have enhanced and contributed much to the technical discussion. However, despite numerous contacts and invitations, this did not materialize. This limitation has highlighted the lack of multinational mechanisms that could facilitate and would promote dialogue with BES structures. 
Taking from the results observed in this study, the following concluding points can be highlighted: i) availability of a protocol to North American borders; international borders are defining their priorities and actions at these regions together with stakeholders and partners from neighboring countries and the existence of border laboratories; ii) because this is a study, among the few, focused on border epidemiological surveillance in the Americas' Southern Cone countries, this research has raised questions about borders that require special attention to delineate and help the flow of work processes; iii) the continuous, systematic development of surveillance systems at the borders will provide more effectiveness to the implementation of actions and responses; thus, countries can improve their mechanisms to respond in future outbreaks; $i v$ ) considering the external validity of this study, the results achieved do not necessarily apply to the reality of other borders; however, the instrument used in this research can be adapted to be used in studies that deal with border surveillance in other parts of the world.

\section{ACKNOWLEDGEMENTS}

This research was funded by the Coordenação de Aperfeiçoamento de Pessoal de Nivel Superior (CAPES) and had the collaboration of the Division of Global Migration and Quarantine (DGMQ) of the Center for Disease Control and Prevention (CDC/US).

\section{REFERENCES}

1. Fineberg HV. Pandemic preparedness and response - lessons from the H1N1 influenza of 2009. N Engl J Med. 2014;370:1335-42.

2. Smith RD. Responding to global infectious disease outbreaks: lessons from SARS on the role of risk perception, communication and management. Soc Sci Med. 2006;63:311323.

3. Centers for Disease Control and Prevention (CDC). Updated information on the epidemiology of Middle East Respiratory Syndrome Coronavirus (MERS-CoV) infection and guidance for the public, clinicians, and public health authorities, 20122013. MMWR Morb Mortal Wkly Rep. 2013;62:793-6.

4. Bond KC, Macfarlane SB, Burke C, Ungchusak K, Wibulpolprasert $\mathrm{S}$. The evolution and expansion of regional disease surveillance networks and their role in mitigating the threat of infectious disease outbreaks. Emerg Health Threats J. 2013;6:19913.

5. World Health Organization. WHO statement on the first meeting of the International Health Regulations (2005) (IHR 2005). Emergency Committee on Zika virus and observed increase in neurological disorders and neonatal malformations. Geneva: WHO; 2016. [cited 2016 Aug 20]. Available from: http://www. who.int/mediacentre/news/statements/2016/1st-emergencycommittee-zika/en/

6. Petersen E, Wilson ME, Touch S, McCloskey B, Mwaba P, Bates M, et al. Rapid spread of Zika virus in the Americas - implications for public health preparedness for mass gatherings at the 2016 Brazil Olympic Games. Int J Infect Dis. 2016;44:11-5.

7. World Health Organization. International health regulations (2005). 2nd ed. Geneva: WHO; 2008. [cited 2016 Aug 10]. Available from: http://apps.who.int/iris/ bitstream/10665/43883/1/9789241580410_eng.pdf

8. Peiter P, Machado O, Iñiguez RL. Doenças transmissíveis na Faixa de Fronteira Amazônica: o caso da malária. In: Miranda AC, Barcellos C, Moreira JC, Monken M, organizadores. Território, ambiente e saúde. Rio de Janeiro: Fiocruz; 2008. p.257-72.

9. Weinberg M, Waterman S, Lucas CA, Falcon VC, Morales PK, Lopez LA, et al. The U.S.-Mexico Border Infectious Disease Surveillance project: establishing bi-national border surveillance. Emerg Infect Dis. 2003;9:97-102.

10. Pindolia DK, Garcia AJ, Huang Z, Fik T, Smith DL, Tatem AJ. Quantifying cross-border movements and migrations for guiding the strategic planning of malaria control and elimination. Malar J. 2014;13:169.

11. Becerril-Montes P, Said-Fernández S, Luna-Herrera J, CaballeroOlín G, Enciso-Moreno JA, Martínez-Rodríguez HG, et al. A population-based study of first and second-line drug-resistant tuberculosis in a high-burden area of the Mexico/United States border. Mem Inst Oswaldo Cruz. 2013;108:160-6.

12. Silva-Sobrinho RA, Andrade RL, Ponce MA, WysockilI AD, Brunello ME, Scatena LM, et al. Delays in the diagnosis of tuberculosis in a town at the triple border of Brazil, Paraguay, and Argentina. Rev Panam Salud Publica. 2012;31:461-8.

13. Oliveira RB, Horta, MA, Barbosa DS, Belo VS, Verani JF. Emergências em saúde pública de importância nacional e internacional no brasil, 2006-2012. Rev Saude Publica Santa Catarina. 2014;7:17-32.

14. Moore M, Dausey DJ. Local cross-border disease surveillance and control: experiences from the Mekong Basin. BMC Res Notes. 2015;8:90.

15. Peiter PC. Condiciones de vida, situación de la salud y disponibilidad de servicios de salud en La frontera de Brasil: un enfoque geográfico. Cad. Saude Publica. 2007;23 Suppl 2:S237-50.

16. Mumme SP, Collins K. The La Paz Agreement 30 years on. J Environ Dev. 2014;23:303-30.

17. United States-Mexico Border Health Commission. Border region. [cited 2016 July 5]. Available from: http://www.borderhealth. org/border_region.php

18. Suter TT, Flacio E, Feijoó FB, Engeler L, Tonolla M, Regis LN, et al. Surveillance and control of Aedes albopictus in the SwissItalian border region: differences in egg densities between 
intervention and non-intervention areas. PLoS Negl Trop Dis. 2016;10:e004315.

19. Instituto Brasileiro de Geografia e Estatística. Censo 2010. Brasília: IBGE; 2010. [cited 2016 April 18]. Available from: http://www.censo2010.ibge.gov.br

20. Center for Disease Control and Prevention. Framework for program evaluation in public health. MMWR Recomm Rep. 1999;48(RR-11):1-40

21. Bruniera-Oliveira R, Horta MA, Verani JF. Avaliação da vigilância epidemiológica ampliada do rotavírus. Rev Bras Promoç Saúde. 2014;27:140-8.

22. Varan A, Bruniera-Oliveira R, Peter CR, Fonseca-Ford M, Waterman S. Multinational disease surveillance programs: promoting global information exchange for infectious diseases. Am J Trop Med Hyg. 2015;93:668-71.

23. Likert RA. Technique for the measurement of attitudes. Arch Psychol.1932;22:1-55

24. Vagias WM. Likert-type scale response anchors. Clemson: Clemson University; 2006.

25. Allen IE, Seaman CA. Likert scales and data analyses. Qual Prog. 2007. [cited 2017 July 21] Available from: http://asq org/quality-progress/2007/07/statistics/likert-scales-and-dataanalyses.html

26. Center for Disease Control and Prevention. Technical guidelines for United States-Mexico coordination on public health events of mutual interest. [cited 2016 Aug 10]. Available from: https:// www.cdc.gov/usmexicohealth/pdf/us-mexico-guidelines.pdf

27. Delbiso TD, Rodriguez-Llanes JM, Altare C, Masquelier B, GuhaSapir D. Health at the borders: Bayesian multilevel analysis of women's malnutrition determinants in Ethiopia. Glob Health Action. 2016;9:30204.

28. Ferraz AF, Valente JG. Epidemiological aspects of pulmonar tuberculosis in Mato Grosso do Sul, Brazil. Rev Bras Epidemiol. 2014;17:255-66.

29. Spradling PR, Xing J, Phippard A, Fonseca-Ford M, Montiel S, Guzmán NL, et al. Acute viral hepatitis in the United StatesMexico border region: data from the Border Infectious Disease Surveillance (BIDS) Project, 2000-2009. J Immigr Minor Health. 2013;15:390-7.
30. Wang HB, Zhang LF, Yu WZ, Wen N, Yan DM, Tang JJ, et al. Cross-border collaboration between China and Myanmar for emergency response to imported vaccine derived poliovirus case. BMC Infect Dis. 2015;15:18.

31. Brasil. Ministério da Saúde. Gabinete do Ministro. Portaria $\mathrm{n}^{\mathrm{o}} 2.761$, de 18 de novembro de 2008. Aprova a Resolução GMC n' 22, "Vigilância epidemiológica e controle de enfermidades priorizadas e surtos entre os estados partes do Mercosul". Diário Oficial da União, Brasília, 19 nov. 2008. p. 116 [Cited 2017 July 21]. Available from: http://www. saude.sp.gov.br/resources/ses/legislacao/2008/novembro/ informe-eletronico-de-legislacao-em-saude-n-221-21.11.2008/ legislacaofederal/u_pt-ms-gm-2761_181108.pdf

32. Goodfellow I, Reusken C, Koopmans M. Laboratory support during and after the Ebola virus endgame: towards a sustained laboratory infrastructure. Euro Surveill. 2015;20:pii=21074.

33. Millman AJ, Chamany S, Guthartz C, Thihalolipavan S, Porter M, Schroeder A, et al. Active monitoring of travelers arriving from Ebola-affected countries -New York City, October 2014 - April 2015. MMWR Morb Mortal Wkly Rep. 2016;653:51-4.

34. Cerroni MP, Carmo EH. Magnitude das doenças de notificação compulsória e avaliação dos indicadores de vigilância epidemiológica em municípios da linha de fronteira do Brasil, 2007 a 2009. Epidemiol Serv Saude. 2015;24:617-28.

35. Mercado Común Del Sur. En pocas palabras. Montevidéo: MERCOSUR; 2015. [cited 2016 July 22]. Available from: http://www.mercosur.int/innovaportal/v/3862/4/innova.front/ en_pocas_palabras

36. Waterman SH, Escobedo M, Wilson T, Edelson PJ, Bethel JW, Fishbein DB. A new paradigm for quarantine and public health activities at land borders: opportunities and challenges. Public Health Rep. 2009;124:203-11.

37. Bajardi P, Poletto C, Ramasco JJ, Tizzoni M, Colizza V, Vespignani A. Human mobility networks, travel restrictions, and the global spread of $2009 \mathrm{H} 1 \mathrm{~N} 1$ pandemic. PloS One. 2011;6:e16591.

38. Mateus AL, Otete HE, Beck CR, Dolan GP, Nguyen-Van-Tam JS. Effectiveness of travel restrictions in the rapid containment of human influenza: a systematic review. Bull World Health Organ. 2014;92:868-80. 